\title{
The Effect of Blended Learning to the Students Learning Achievements in Department of Mechanical Engineering
}

\author{
Andri Setiyawan ${ }^{1}$, Taofan Ali Achmadi ${ }^{1}$, Ayub Budhi Anggoro ${ }^{1}$ \\ ${ }^{I}$ Faculty of Engineering, Semarang State University, Semarang, Indonesia \\ \{andryaam, taofanali,anggoroayub\}@gmail.com
}

Keywords: Blended Learning Method, Learning Achievement.

\begin{abstract}
Blended learning is a lecturer learning concept supported by e-learning so that it could be complement each other's in shortcomings. This study aims to determine the effect of blended learning on students learning achievement in Mechanical Engineering Department, including: (1) the significant improvement of student's achievement before and after using the blended learning method; and (2) the significance differences in student's achievements between students who use and do not use blended learning method. This research was quasi experimental research using the pretest-posttest non-equivalent control group design. The sample were students of mechanical engineering department consist of 30 students as group control and 30 students as group experimental. The data collected through assessments of pertest and posttests result were analysed using the t-test. The results showed that: (1) there was significant improvement in student achievement (Sig. $0.00<0.05$ ) after applied the blended learning method; and (2) there is significant difference of student achievement (Sig. $0.00<0.05$ ) between experimental group using blended learning and control group using lecture method. Hence, blended learning method has an effect on students achievement.
\end{abstract}

\section{INTRODUCTION}

Learning is a relatively constant process of behaviour change. The process of change does not occur at once but occurs gradually depending on the learning support factors that affect students. According to Daryanto (2010: 36), these factors can generally be divided into two groups, namely the factors that originate in the learner (internal) include physical, psychological and error factors while the factors that come from outside the student's self (external) includes family, school and community factors. These factors are very influential on student learning achievement because the success of achieving a stage of learning outcomes allows students to learn more smoothly in reaching the next stage.

Based on observations in class when implementing PPL (August 9 to September 16, 2014), most of the teachers used the lecture method in the process of teaching and learning activities in the Mechanical Engineering Department of Muhammadiyah 3 Vocational School Yogyakarta. Djamarah and Zain (2013: 97) state the lecture method is a way of presenting lessons conducted by the teacher with narrative or direct verbal explanations to students. In its implementation, the lecture method itself has strengths and weaknesses.

By using the lecture method, the material given decomposes clearly, can convey information quickly, can be used for the number of students and large class sizes. While regarding the weakness of this method, according to Wina Sanjaya (2008: 189) there are three things weaknesses in the lecture method, which is only for good listening and listening skills, cannot serve differences in student abilities, only emphasizes one-way communication. Referring to the weaknesses above, the teacher lecture method is still a player and students become spectators, active teachers and passive students. The impact that occurs from the existing fact causes the readiness of students to attend classes ineffective, this can be seen when the learning process takes place some students are still engrossed in talking with their friends, sleepy, saturated and others.

It is time for learning to be supported by an elearning based learning concept that uses electronic circuits (LAN, WAN, or internet) to convey the contents of learning, interaction, or guidance (Jaya 
C. Koran, 2002). The use of electronic media here is defined as the use of electronic media in the learning process as a tool for its assistance. The electronic media can be in the form of internet, TV, radio, simulators, CD ROMs, and so on. With this principle, the concept of e-learning is very helpful in the learning process, especially in the delivery of material because it can attract students' interest in taking lessons and students are motivated to understand the contents of the subject matter. However, in the implementation of the use of elearning can not be fully realized because students often can not divide time and utilize information provided independently and still lack of knowledge about the use of e-learning itself and the strong influence of the lecture method for teachers.

Based on the problems as previously described, a solution is needed to cover the weaknesses of the lecture method and the e-learning system itself. Blended Learning method is the right alternative to be used in the learning process. Rusman (2012: 303 ), states that blended learning is a combination of various approaches in learning. The blended learning method is a combination of face-to-face learning models and e-learning based learning models that utilize electronic media. That is, blended learning is a lecture learning model that is supported by elearning based learning models so that the learning process will run optimally because the advantages of the two models will be able to complement each of the shortcomings of the two learning models. In its practical language, the blended learning method offers the possibility to benefit from a class that supports the direct interaction and flexibility of online learning and the use of learning media.

Ali (2007) in his research showed that through the application of the blended learning model there was an increase in student learning outcomes in the electromagnetic field course at the Electrical Engineering Department of the Faculty of Engineering, YSU from 58.6 to 73.4. While the results of the study from Siti Nur Alfath (2013) showed that in the Basic Physics 2 subject of the Physics Department of UNNES there was an increase in student learning outcomes seen from the average student learning outcomes before being subjected to $65.57 \%$ (good category) then after being subjected to experience increase to $75.50 \%$ (good category).

From several studies that have been conducted, it shows that there are influences from the implementation of blended learning methods. Therefore, a blended learning method will be applied in class XI of the Mechanical Engineering of Muhammadiyah Vocational High School 3 of Yogyakarta to improve student learning achievement.

\section{METHODS}

This study uses a quasi-experimental design. This design aims to obtain information that is an estimate of information that can be obtained by actual experiments in circumstances that do not allow to control or manipulate all the variables that are voluntary (Suryabrata, 2013: 93). The systematic description of the design is explained in the following figure.

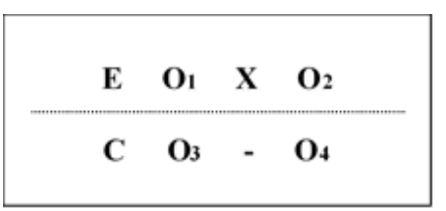

Figure 1. Pretest-posttest control group design

This design was chosen based on the nature of the problem and the research hypothesis. The study design consisted of two groups: the experimental group (30 students) and the control group (30 students). In the experimental group given the treatment of learning using the blended learning method and the control group using traditional methods. Then both groups were given post-test.

\subsection{Research Samples}

The study sample consisted of eleven classes majoring in machining techniques. Determination of the sample using simple random sampling technique. The final sample obtained consisted of 6012 th grade students who were enrolled in engineering majors. The sample consisted of the experimental group ( $\mathrm{n}=$ $30)$ and the control group $(n=30)$.

\subsection{Procedure}

The procedure used in this study is to study the problem and develop a theoretical basis, compile the instrument, take data, select the data according to the specified criteria, make an assessment of the respondent's answer, analyze the data, and make conclusions. 
Table 1: Data analysis of the experimental group pretest

\subsection{Instrument and Technique of Collecting Data}

The data collection technique consists of 2 types, namely 1) documentation using instruments in the form of document sheets; and 2) tests using multiple choice test instruments. The documentation technique aims to obtain written data regarding the state of the research subject in the form of a list of student names, number of students and other data that will be used for research purposes. While regarding the test instrument, in the form of a multiple choice test as many as 50 items with five answer choices, the measurement scale for each test item gets a score of 1 if the answer is correct and 0 if the answer is wrong.

\subsection{Data Analysis Technique}

The analysis tool used to describe the data consists of mean (median), median (middle value), mode, and group variation through the range and standard deviation.

\subsubsection{Test Analysis Requirements}

Requirement analysis test consists of homogeneity test and normality test. Homogeneity test is conducted to find out whether the sample comes from the same variance or not. The test used in the homogeneity test is the F test. While the normality test aims to determine whether the distribution of variables is normal or not. The data normality test technique uses Chi Squared prices.

\subsubsection{Hypothesis Testing}

Testing the hypothesis in this study using the t-test to get the price $t$ count. Then the price of $t$ count compared to $t$ table. If $t$ count is greater than $t$ table, then Ho is rejected and $\mathrm{Ha}$ is accepted. Whereas if $\mathrm{t}$ count is smaller than $t$ table then Ho is accepted and $\mathrm{Ha}$ is rejected.

\section{FINDINGS}

\subsection{Pretest Result}

From the learning outcomes of the pretest from 30 students of the experimental group obtained the following data shown in table 1 .

\begin{tabular}{cc}
\hline Data & Total \\
\hline Maximum score & 70 \\
\hline Minimum score & 32 \\
\hline Mean & 52,2 \\
\hline Median & 52 \\
\hline Mode & 54 \\
\hline Standard deviation & 8,27 \\
\hline
\end{tabular}

The table above shows the highest value obtained by the experimental group students by 70 with a standard deviation of 8.27. The average overall score of students in the experimental group is 52.2

Furthermore, from the learning outcomes of the pretest 30 students of the control group obtained the following data shown in table 2.

Table 2: Pretest control group data analysis

\begin{tabular}{cc}
\hline Data & Total \\
\hline Maximum score & 66 \\
\hline Minimum score & 32 \\
\hline Mean & 49,40 \\
\hline Median & 49 \\
\hline Mode & 50 \\
\hline Standard deviation & 6,71 \\
\hline
\end{tabular}

The table above shows the highest obtained by the experimental group students at 66 with a standard deviation of 6.71 . The average overall score of the experimental group students is 49.4

\subsection{Posttest Results}

From the post test results of the study 30 students of the experimental group obtained the following data shown in table 3 .

Table 3. Analysis of experimental posttest data

\begin{tabular}{cc}
\hline Data & Total \\
\hline Upper Score & 86 \\
\hline Minimum score & 70 \\
\hline Mean & 78,6 \\
\hline Median & 78 \\
\hline Mode & 80 \\
\hline Standard deviation & 2,90 \\
\hline
\end{tabular}


Table 6. Data on experimental normality test data

The table above shows the highest value obtained by the experimental group students by 66 with a standard deviation of 6.71. The average overall score of the experimental group students is 49.4 .

From the posttest learning outcomes 30 students of the control group obtained the following data shown in table 4.

Table 4. Analysis of the control group posttest data

\begin{tabular}{cc}
\hline Data & Total \\
\hline Maximum score & 76 \\
\hline Minimum score & 48 \\
\hline Mean & 63,20 \\
\hline Median & 64 \\
\hline Mode & 66 \\
\hline Standard deviation & 5,77 \\
\hline
\end{tabular}

The table above shows the highest value obtained by the experimental group students at 76 with a standard deviation of 5.77. The average overall posttest value of the control group students is 63.20 .

\subsection{Testing Requirements Analysis}

Homogeneity testing in this study is to use the F test. The homogeneity test results that have been carried out can be seen in the following table 5 .

Table 5. Pretest homogeneity test experiments and control groups

\begin{tabular}{|c|c|c|c|}
\hline Data & F count & F table & NB \\
\hline $\begin{array}{c}\text { Pretest and } \\
\text { Pretest }\end{array}$ & 1,52 & 1,86 & Homogen \\
\hline
\end{tabular}

The data above shows that the price of $\mathrm{F}$ count is smaller than the price of $\mathrm{F}$ table $(\mathrm{Fh}=1.52<\mathrm{Ft}=$ 1.86), so it can be concluded that between the variance of the pretest data of the experimental group with the pretest homogeneous control group.

Normality testing in this study uses the chi square formula $\left(\mathrm{X}^{2}\right)$, then the price of chi squares is calculated compared to the price of chi square tables. The price of the chi square of the table is determined by the error rate of $5 \%$. Data is normally distributed if the price of chi squared counts <chi squared table.

The results of the normality test that has been done can be seen in the following table 6 .

Table 6. Data on experimental normality test data
\begin{tabular}{|c|c|c|c|}
\hline Data & $\left(\mathrm{Xh}^{2}\right)$ & $\left(\mathrm{Xt}^{2}\right)$ & $\mathrm{NB}$ \\
\hline Pretest & 3,63 & 11,07 & Normal \\
\hline Posttest & 8,46 & 11,07 & Normal \\
\hline
\end{tabular}

Table 7. Control group normality test data

Table 7. Control group normality test data
\begin{tabular}{|c|c|c|c|}
\hline Data & $\left(\mathrm{Xh}^{2}\right)$ & $\left(\mathrm{Xt}^{2}\right)$ & $\mathrm{NB}$ \\
\hline Pretest & 2,67 & 11,07 & Normal \\
\hline Posttest & 6,90 & 11,07 & Normal \\
\hline
\end{tabular}

The data above shows that the pretest value of the experimental group, the pretest of the control group, the posttest of the experimental group and the posttest of the control group shows the price of chi squares smaller than the price of chi squares $\left(\mathrm{Xt}^{2}\right)$, so parametric statistical techniques.

\subsection{Hypothesis Testing}

Testing the pretest and posttest t-test of the experimental group was used to find out how far the students' learning achievement improved after using the blended learning method. The following are the results of the calculation of the pretest and posttest ttests of the experimental group.

Table 8. Results of the pretest and posttest t-tests of the experimental group

\begin{tabular}{|c|c|c|c|}
\hline Data & $\mathrm{t}$ count & $\mathrm{t}$ table & \multicolumn{1}{|c|}{ NB } \\
\hline $\begin{array}{c}\text { Pretest and } \\
\text { Posttest }\end{array}$ & 16,60 & 2,002 & $\begin{array}{l}\text { Ho rejected and } \\
\text { Ha accepted }\end{array}$ \\
\hline
\end{tabular}

Based on the results of the calculation above, it shows that $\mathrm{t}$ count is greater than at $\mathrm{t}$ table (16.60> 2.002). So it can be concluded that there is a significant increase in student achievement in the subject of lathe machining techniques in class XI of Mechanical Engineering Department of Muhammadiyah 3 Yogyakarta vocational school after being taught using the Blended Learning method.

Whereas to find out whether there are differences in learning achievement between class XI TP4 using the blended learning method and class XI TP2 using conventional methods on the lathe machining technique subjects, here are the results for the calculation of the experimental group and control ttest.

Table 9. Results of the pretest and posttest t-tests of the control group

\begin{tabular}{|c|c|c|l|}
\hline Data & t count & $\mathrm{t}$ tabel & \multicolumn{1}{|c|}{ NB } \\
\hline $\begin{array}{c}\text { Posttest dan } \\
\text { Posttest }\end{array}$ & 13,16 & 2,002 & $\begin{array}{l}\text { Ho rejected and } \\
\text { Ha accepted }\end{array}$ \\
\hline
\end{tabular}


Based on the results of the calculation, the results of $\mathrm{t}$ arithmetic are greater than $\mathrm{t}$ table (13.16> 2.002). So it can be concluded that there are differences in learning outcomes between class XI TP4 using the blended learning method and class XI TP2 using conventional methods on the subject of lathe machining techniques.

\section{DISCUSSION}

This study shows differences in learning outcomes of the experimental group and the control group, where the experimental class learning outcomes are better than the control class. From the results of observations and oral interviews conducted by researchers with experimental class students, conclusions can be drawn including: 1) Blended learning method causes learning to not seem monotonous. 2) Students tend to be more active and feel happy to take lessons using the blended learning method, because in addition to being taught by the lecture method but students can also access the subject matter that has been provided in e-learning equipped with various additional references and various videos about the turning process and equipped with quizzes in measuring the level of student understanding of the material provided. 3) Students feel more effective with the blended learning method, because students do not have to record all the material presented by the teacher because they only need to download the material in e-learning provided in ms.word, pdf, and power point formats to be re-learned by students. 4) Students feel happy to be taught with blended learning methods because in learning in e-learning students can interact in the form of chatting with other students and with their teachers like social media so students feel not awkward in asking questions related to subject matter. The use of blended learning method is an effort to more effectively and optimize student learning activities because with the use of blended learning, the motivation of students to learn increases so that students' learning achievement also increases. Students become happy to learn and become more intense in paying attention to the learning process with the blended learning method.

\section{CONCLUSION}

The study of the effect of the blended learning approach on the learning achievement of class XI
Mechanical Engineering of Muhammadiyah 3 Yogyakarta Vocational High School was concluded that there was a significant increase in student achievement $(\mathrm{t}$ count $=16.60>\mathrm{t}$ table $=2.002)$ after the blended learning method was applied, and there were the difference in student learning achievement is significant $(\mathrm{t}$ count $=13.16>\mathrm{t}$ table $=2.002$ ) between the experimental class that uses blended learning and the control class that uses the lecture method. So that it can be concluded that the application of blended learning methods has an effect on student learning achievement.

\section{REFERENCES}

Daryanto. (2010). Belajar dan Mengajar. Bandung: CV. Yrama Widya.

Koran, jaya Kumar C. (2002), Aplikasi E-learning dalam Pengajaran dan pembelajaran di Sekolah Malaysia.

Muhamad Ali. (2007). Analisis Dampak Implementasi Model Blended Learning: Kombinasi Pembelajaran di Kelas dan E-Learning Pada Mata Kuliah Medan Elektromagnetik. Yogyakarta: UNY Press.

Rusman, Kurniawan D., \& Riyana C. (2012). Pembelajaran Berbasis Teknologi Informasi dan Komunikasi: Mengembangkan Profesionalitas Guru. Jakarta: PT. Rajagrafindo Persada.

Siti Nur Alfath. (2013). Pengembangan Media Blended Learning Berbasis Web Enhanced Course Pada Mata Kuliah Fisika Dasar 2 Jurusan Fisika UNNES. Semarang: UNNES.

Sugiyono. (2012). Statistika untuk Penelitian. Bandung: Alfabeta.

Sugiyono. (2013). Metode Penelitian Kuantitatif, Kualitatif dan $R \& D$. Bandung: Alfabeta.

Sumadi Suryabrata. (2013). Metodologi Penelitian. Jakarta: Rajawali Pers.

Syaiful B. Djamarah, dan Aswan Zain. (2013). Strategi Belajar Mengajar. Jakarta: PT. Rineka Cipta.

Syfa S. Mukrimah. (2014). 53 Metode Belajar dan Pembelajaran. Bandung: UPI.

Wina Sanjaya. (2008). Stategi Pembelajaran. Jakarta: Kencana Prenada Media. 